\title{
Do human rights offenders oppose human rights resolutions in the United Nations?
}

\author{
Bernhard Boockmann • Axel Dreher
}

Received: 12 February 2009 / Accepted: 13 January 2010 / Published online: 27 January 2010

(C) The Author(s) 2010. This article is published with open access at Springerlink.com

\begin{abstract}
We investigate whether countries with poor human rights records oppose human rights resolutions in the United Nations General Assembly. An instrumental account of voting would suggest that these countries aim to weaken resolutions since they could be future targets of these policies. We estimate determinants of voting using 13,000 individual voting decisions from 1980 to 2002 . Our results from ordered probit estimation show that a country's human rights situation is irrelevant to voting behavior if regional dependence of voting is controlled for. The results also show that simple rules for aggregating voting choices can lead to misleading results.
\end{abstract}

Keywords Voting $\cdot$ Human rights $\cdot$ United Nations $\cdot$ Instrumental voting

JEL Classification D78

B. Boockmann

Institute for Applied Economic Research (IAW), Tuebingen, Germany

e-mail: bernhard.boockmann@iaw.edu

B. Boockmann

University of Mannheim, Mannheim, Germany

B. Boockmann · A. Dreher

IZA, Bonn, Germany

A. Dreher $(\bowtie)$

University of Goettingen, Platz der Goettinger Sieben 3, 37073 Goettingen, Germany

e-mail: mail@axel-dreher.de

A. Dreher

CESifo, Munich, Germany

A. Dreher

KOF Swiss Economic Institute, Zurich, Switzerland 


\section{Introduction}

Although there have been a number of papers on voting in international bodies over the last couple of years, voting in international organizations, and in the United Nations General Assembly (UNGA) in particular, is still not fully understood. In particular, the logic behind voting decisions remains largely unexplored: do countries vote to achieve a particular outcome, or is voting best explained by other motives, such as voting blocs, ethical values, or reputation among allies and potential donors?

In this paper, we look at voting on resolutions of the UNGA. The resolutions of the UNGA concern many different policy areas, such as human rights, the situation in particular countries or regions (Israel and West Bank, South Africa), peace and security, and technical issues (budget, admission to committees, etc.). We focus our discussion on a relatively homogenous group of resolutions - those dealing with human rights. For many actors, such as European Union governments, this subject area is among their main priorities within the United Nations (Luif 2003).

The central question of our paper is whether poor human rights records induce countries to oppose UN human rights resolutions. A reason for this would be that successful proposals for resolutions make further resolutions more likely, and countries with poor human rights records could be the targets of future resolutions. Therefore, if these countries dislike resolutions directed against them, there is an instrumental motive for voting against resolutions directed against other countries. While it is often taken for granted that a link between policies adopted domestically and internationally exists, the question whether and to which degree this explains UN decision-making has not been addressed systematically.

In the previous literature, competing accounts of the motives for voting in the UNGA dominate. First, the issue of voting blocs and persistent lines of conflict has been frequently analyzed. Newcombe and Allett (1981) and Holcombe and Sobel (1996) identify voting blocs and their stability. Kim and Russett (1996) and Voeten (2000) analyze voting decisions using techniques such as factor analysis and Poole and Rosenthal's (1991, 1997) NOMINATE methodology. This approach uncovers both the underlying issue-dimensions and the voting preferences among UN member states. Potrafke (2009) focuses on governments' ideology and reports that leftwing governments are on average less likely to be allied with the United States. A second well-researched question is whether voting is related to development aid. Stone $(2002,2004)$ shows that governments receiving more UN foreign aid receive lighter punishments for non-compliance with policy conditions under IMF programs. Kilby (2006) reports that voting alignment with Japan in the UN reduces funding by the Asian Development Bank in the first half of the sample investigated but increases funding in the more recent period. According to Kilby (2009a), the World Bank enforces its structural adjustment conditions less rigorously in countries voting in line with the United States in the UNGA. Dreher et al. (2008) use disaggregated aid data to account for the fact that various forms of aid may differ in their ability to induce political support by recipients. They obtain strong evidence that US general budget support and untied grants buy voting compliance in the UNGA. Dreher and Sturm (2006) analyze voting coincidence with major countries, in particular with countries influential for multilateral aid and credits. Thacker (1999) shows that governments moving to the US position on key issues in the UNGA are more likely to participate in IMF programs - presumably as the IMF loan acts as a reward.

In comparison with the numerous studies for other voting bodies (in particular, the US Congress), these studies provide only selective evidence. At the national level, the relative importance of voting motives has been investigated in a number of studies. Levitt (1996), Rothenberg and Sanders (2000), Snyder and Groseclose (2000), Fleck and Kilby (2001, 
2002), Broz and Hawes (2006), and Broz (2008) focus on the determinants of the individual voting decision. Using discrete choice techniques, a distinction can be made between different motives of voting, such as constituent interest, party affiliation, or personal ideology. Buying votes is also a theme in research on national elections (Levitt and Snyder 1997; Dahlberg and Johansson 2002; Stratmann 1991, 1998). Concerning international organizations, Boockmann (2003) for the ILO and Hix et al. (2006) as well as Hosli (2007) for the European Parliament have tried to disentangle the different motives of voting. ${ }^{1}$

Precisely because the role of different motives and the voting act is treated as a black box, existing studies have to rely on ad-hoc procedures in coding the different voting alternatives. In particular, is voting against a particular issue a close substitute for abstention, such that both choices can be merged into one? Or does abstention signify indifference? Since we analyze the determinants of voting decisions at the individual level, evidence on these questions is provided as a by-product of our study.

In summary, we offer three contributions to this literature: First, we are the first to test for the existence of an instrumental motive in voting on human rights. Second, we investigate the role of abstentions and evaluate whether voting against a particular issue can be regarded as substitute for abstention, or whether abstention signifies indifference. And third, we investigate whether voting on human rights is independent across countries. Our results show that individual countries' human rights records are not influential for voting. We also find that cohesion within regional groups is important. And finally, abstentions and votes against resolutions are regarded as different alternatives by UNGA members.

The remainder of the paper is structured as follows. We first introduce human rights decisions as the object of the voting decisions studied. In section three, we develop some hypotheses as to how voting behavior can be explained. Next, we explain how these hypotheses can be tested, introducing the data and the approach used for estimation. In Sect. 5, we present the results. Conclusions and the relation of our results to previous findings are contained in a final section.

\section{Voting on human rights in the UN General Assembly}

Since the Universal Declaration of Human Rights of 1948, the issue of human rights has been one of the most important policy areas of the organization. A number of different UN bodies in which human rights are addressed exists over the years included in our sample, such as the Human Rights Council, the Commission on Human Rights, the Sub-Commission for the Promotion and Protection of Human Rights, human rights treaty bodies such as the Human Rights Committee, the Committee on Economic, Social and Cultural Rights, and many others. ${ }^{2}$ We focus on the human rights resolutions of the main deliberative organ of the UNGA. Voting in the UNGA is frequent and often conducted as a roll-call, such that the voting behavior of UNGA members is documented. Therefore, UNGA decision-making is particularly apt to statistical analysis.

\footnotetext{
${ }^{1}$ For a general discussion of motives for voting see Tullock (2006).

${ }^{2}$ The Human Rights Council succeeded the Commission on Human Rights in 2006. It is a subsidiary body of the General Assembly and reports directly to it. The Sub-Commission on the Promotion and Protection of Human Rights was the main subsidiary body of the Commission on Human Rights. The Human Rights Committee consists of 18 experts discussing the reports submitted by $162 \mathrm{UN}$ member states on their compliance with the International Covenant on Civil and Political Rights, while the Committee on Social Economic and Cultural Rights' experts discuss the reports submitted by UN member states on their compliance with the International Covenant on Economic, Social and Cultural Rights.
} 
Table 1 Statistics on UNGA voting, 1980-2002
Number of cases

UNGA resolutions adopted

1980-1989

2990

1990-2002

4568

Recorded votes on UNGA resolutions

1980-1989

1990-2002

931

Recorded votes on UNGA human rights resolutions (our definition) 1980-1989

1990-2002

It is not obvious how to define what constitutes an UNGA human rights resolution. A straightforward procedure is to use the title of the resolution as an indication. Recent resolutions with the phrase "human rights" in their title include texts on general problems such as the impact of globalization on human rights, but also the human rights situations in specific countries. In 2005, for example, resolutions criticizing the human rights situations in North Korea, Iran, Uzbekistan, Turkmenistan, Congo, and Myanmar have been approved. Some topics, such as resolutions concerning the rights of children or practices in particular countries, can easily be identified as human rights issues. Classifying human rights votes is more difficult for topics such as "the right to development" or "economic rights." Rather than propagating liberal human rights, these resolutions may formulate demands for financial aid and express political goals different from, and sometimes opposed to, liberal human rights. $^{3}$

However, since the borderline is unclear, we chose to include into our sample of resolutions all resolutions having the words "right" or "rights" in their title, except for those that relate to the Palestinian-Israeli conflict, which are regarded as belonging to a different subject area. Our analysis rests on the universe of recorded votes held from 1980 to 2002 on resolutions in the group just defined. ${ }^{4}$ Resolutions are either adopted by consensus or, if requested by at least one member, by a recorded vote (or roll-call vote). Table 1 provides some background statistics. We report the statistics separately by decade, which coincides with the end of the Cold War. According to Kim and Russett (1996), the East-West divide explains a large share of the variation in (overall) voting behavior during the Cold War, but not thereafter. Arguably, such change might also be reflected in the number of resolutions adopted without formal voting. As the table shows, only a minority of resolutions are voted on. These resolutions are unlikely to be representative for all resolutions brought before the UNGA. Therefore, any conclusions drawn from UNGA voting data cannot be extended to statements on the distribution of voting intentions or preferences in the UNGA in general. ${ }^{5}$

\footnotetext{
${ }^{3}$ While most relevant resolutions have the words "human rights" in the title, many do not. This is even if they are clearly dealing with human rights in the liberal sense, such as Resolution A/RES/39/137 on Civil and Political Rights, A/RES/41/151 on Migrant Workers' Rights, or A/RES/42/101 on the Convention on the Rights of the Child. All in all, 33 of 173 resolutions in our sample are resolutions on "Rights" but not "Human Rights." Of these, 15 deal with "Economic Rights," the "Right to Development" and the "Right to Food."

${ }^{4}$ The choice of sample period is driven by data availability. While UN voting records are available for a substantially longer period, some of our control variables are not.

${ }^{5}$ Thiem (2006) has addressed the incentive to call a roll-call with respect to the European Parliament. However, this issue would require a different data base and is, therefore, left to further research.
} 
Table 2 Recoding procedure

\begin{tabular}{llll}
\hline & \multicolumn{2}{l}{ Benchmark countries voting } \\
\cline { 2 - 4 } Country voting & YES & ABSTENTION & NO \\
\hline YES & in favor & against & against \\
ABSTENTION & neutral & in favor & $\begin{array}{l}\text { neutral } \\
\text { NO }\end{array}$ \\
against & against & in favor \\
\hline
\end{tabular}

This is particularly true for the situation after 1990, where decisions have less often been made by roll-call voting. Table 1 also shows that voting on resolutions on human rights represents only a small share of all voting on UNGA resolutions: roughly one out of ten votes concerns human rights issues.

Each member of the UNGA has one vote. Human rights resolutions are adopted by simple majority, i.e., for a resolution to be adopted, a majority of votes cast as yes or no must be found. Abstentions do not count in the determination of the outcome. No decisions may be taken unless a quorum of a majority of UN members are present. However, the possibility of a quorum not being reached does not appear to be an issue, as it is never even mentioned in the verbatim reports of the UNGA sessions.

Data on the voting behavior of each country on every roll call vote in the UNGA since 1946 has been collected by Voeten (2004). These data have been assembled from the records of resolutions passed. Hence, information on votes on unsuccessful resolutions is missing. However, these gaps in the data are minor. For instance, in the years 1988-1992, no resolution failed in the UNGA. Except for conventions on taking hostages and hijacking, all major resolutions have been adopted since the late 1980s (Gstöhl 2006). Therefore, selectivity is not an issue here and omitting failed resolutions is in line with the previous literature. ${ }^{6}$

It is not straightforward to classify voting decisions as for or against a strengthening of human rights. Voting behavior must be recoded, since nominal voting behavior (such as yes and no) is not informative without knowing the subject of the vote. In the case of human rights, we need to code voting as for or against more strongly worded resolutions. For instance, some human rights resolutions may actually weaken human rights (such as the Resolution on Coercive Measures against Human Rights), some may be deflecting attention (e.g., by stressing self-determination of countries rather than individual liberties, such as Resolution 32/130 on Human Rights, Future Approaches). Coding each individually would bring about the danger of arbitrary judgments.

Instead, we proceed by selecting benchmark countries. A benchmark country is a country that is very likely to pick the alternative favorable to the propagation of liberal human rights. We use the voting outcome chosen by the majority of the following countries: France, Germany, the Netherlands and the UK. These countries have the highest degree of voting for the ten most recent human rights resolutions, according to Human Rights Watch, one of the most important NGOs in the human rights field. ${ }^{7}$ If at least two of these countries choose yes or no, this is the outcome selected as a benchmark. Otherwise, the benchmark is abstention. In 150 of all 173 votes on human rights resolutions, the four benchmark countries were unanimous. In six cases, one benchmark country abstained and in 17 cases, two countries abstained. Almost all of these cases of disagreement concern resolutions in the early 1980s.

The dependent variable is coded according to the following rules (Table 2): if the benchmark countries voted in favor of the resolution, nominal voting decisions are used directly as

\footnotetext{
${ }^{6}$ See, for instance, Marín-Bosch (1998) and Dreher and Jensen (2007).

${ }^{7}$ See http://www.hrw.org/un/elections/index.htm.
} 
Table 3 Statistics for voting behavior on human rights resolutions. Note: Numbers in parentheses indicate percentages

\begin{tabular}{lll}
\hline & $1980-1989$ & $1990-2002$ \\
\hline Nominal voting behavior & & \\
Yes & 9,135 & 9,484 \\
& $(76.69)$ & $(64.06)$ \\
Abstention & 2,174 & 3,651 \\
& $(18.25)$ & $(24.66)$ \\
No & 603 & 1,671 \\
& $(5.06)$ & $(11.29)$ \\
Human rights position & & \\
In favor & & 7,499 \\
& 5,552 & $(50.65)$ \\
Abstention & $(46.61)$ & 3,122 \\
& 1,594 & $(21.09)$ \\
Against & $(13.38)$ & 4,185 \\
& 4,766 & $(28.27)$ \\
All votes & $(40.01)$ & 14,806 \\
Non-participation & 11,912 & $(100.00)$ \\
& $(100.00)$ & 1,102 \\
& 749 &
\end{tabular}

a measure of human rights voting. If the benchmark countries opposed a resolution, the reverse applies: a vote in favor is interpreted as a vote against human rights. If the benchmark countries abstained, which is true in $20 \%$ of all votes, all votes other than abstention are interpreted as votes against human rights. An alternative specification implying that abstention means resistance against a resolution did not yield qualitatively different conclusions. However, our empirical results indicate that abstentions and votes against should be treated as different alternatives (see Sect. 5).

The upper part of Table 3 shows that most votes that have been cast are approvals of draft resolutions. This is particularly true for the period before 1990, where more than threequarters of all votes on human rights resolutions are votes in favor, and only $5 \%$ are votes against. However, the lower half of the table shows that this does not imply universal approval of human rights. In particular, prior to $1980,40 \%$ of the votes were cast against the position of human rights proponents. After 1990, relatively more abstentions occur, but the support for resolutions in favor of human rights has increased only slightly. Hence, even if variation in voting appears to be limited at first sight, the actual variation in voting, and hence the amount of conflict over human rights, remains high at the United Nations.

\section{Explaining UNGA voting}

Our main question is the degree to which voting behavior in the UNGA is motivated by countries' (or national politicians', or their constituents') interests in the outcome of the vote. In the public choice literature, this motive is called the instrumental benefit of voting. The benefit of voting for the preferred alternative stems from the enhanced chances that this alternative will be chosen as a voting outcome (Riker and Ordeshook 1968; Ledyard 1984). A well-known alternative is expressive voting (see Brennan and Hamlin 1998). 
It might be argued that the instrumental benefit in UNGA voting is zero, since resolutions are almost always adopted with sizeable majorities, such that the impact of any individual country's vote is negligible. On average, the difference between the number of votes in favor and votes against is 94 in our sample of human rights decisions, with a standard deviation of 36 . However, even in cases of certain adoption, the size of the majority may be a highly relevant outcome. The larger the majority with which international norms have been adopted, the higher is their degree of moral dignity. Therefore, member states may find it costly to act against UNGA resolutions having found wide acceptance. By contrast, if a resolution had received only a slight majority, it may lack moral force and be easily disrespected. In this sense, there is an instrumental benefit from voting, arising because resolutions may be strengthened or weakened by individual voting acts. Countries aiming at improved protection of human rights have an instrumental motive for voting in favor, because a stronger resolution is beneficial for the realization of their policy objective. Conversely, countries that oppose the role of the United Nations in the protection of human rights have an instrumental motive either to vote against or abstain. It is likely that the instrumental motive differs across subjects. For instance, technical issues (such as technical standards or administrative procedures) are simply settled by the vote. The size of the majority is unlikely to be important. ${ }^{8}$ On other issues, the size of the majority matters if general obligations are formulated.

Opposition to human rights policies may originate for different reasons, but a leading reason is that these policies directly impact on countries' interests. As a result of UN resolutions, countries condemned for their human rights practices may face direct and indirect sanctions. For instance, as Lebovic and Voeten (2006) show, the adoption of a United Nations Commission on Human Rights (UNCHR) resolution condemning a country's human rights record results in a sizeable reduction in multilateral—and especially World Bankaid. Hence, there is a strong reason for countries to oppose UN resolutions directed against them. Similarly, if a country is not a target of the present resolution but, due to its human rights practices, could become a target of future UN resolutions, it also has an instrumental motive for voting. By voting against, it may discourage other states from bringing forward future draft resolutions, and ultimately decrease the chances of future public condemnation. This may be a reason why, in our data, voting against human rights is relatively frequent. For these reasons, we use countries' human rights conditions as a proxy variable for the instrumental benefit of voting in our estimations.

There is a number of reasons why countries may not vote according to their perceived instrumental benefits. A prominent reason stems from the fact that voting is public. Governments may judge each others' policies and intentions by their voting behavior. There is ample evidence that G7 governments place some weight on voting behavior in the UNGA. This is particularly true for the US. As has been pointed out by the US Department of State (1985), examining UN votes makes it possible "to make judgments about whose values and views are harmonious with our own, whose policies are consistently opposed to ours, and whose practices fall in between." A 2000 report from the U.S. State Department states that "a country's behavior at the United Nations is always relevant to its bilateral relationship with the United States, a point the Secretary of State regularly makes in letters of instruction to new U.S. ambassadors" (quoted in Andersen et al. 2006). As a consequence of the G7's monitoring of voting behavior, countries may wish to be observed voting for or against a particular resolution in order to signal a friendly or unfriendly attitude to one another, or because they want to be seen as partisan in particular policy areas. As opposed to the prediction

\footnotetext{
${ }^{8}$ See Stigler (1972) for a discussion.
} 
from instrumental voting, countries with poor human rights records may have an incentive to improve their public standing by voting for human rights resolutions. Following Volgy et al. (2003), we label votes that have been modified in response to pressure as "modified preferences." According to Volgy et al., the fact that surprisingly many states with different cultural, political and geographic backgrounds vote the same on a wide range of issues indicates such modified preferences.

A mechanism that has often been addressed in this context is the relation between voting and development aid. It has been argued that the "State Department ... places high value on the employment of foreign aid to ... swing critical votes in international bodies" (Black 1968, p. 19). Thacker (1999, p. 54) cites a memo to the director of the Food for Peace Program noting that "at critical moments in the world's recent history, the U.S. 'bought' votes subtly and indirectly to support its stand in the General Assembly." Bennis (1997) claims that "U.S. influence in (and often control of) the UN comes in the form of coercing the organization to take one or another position, or to reject some other position, or pressuring a country or countries to vote a certain way in the General Assembly." As a specific example of US pressure on the UNGA, Bennis describes the US effort to overturning the 1975 resolution identifying political Zionism as a form of racism and racial discrimination. According to Bennis, "U.S. diplomats took off, criss-crossing the globe using Gulf War-tested methods of bribing and threatening other nations to win support for the repeal effort." 9

The nexus between aid and UN voting has been examined empirically in a number of studies. Alesina and Dollar (2000), Alesina and Weder (2002) as well as Gates and Höffler (2004) all consider UN voting behavior of recipients as political determinants of bilateral aid. Alesina and Weder (2002) show that the United States rewards recipients' voting compliance by granting more aid; Alesina and Dollar (2000) as well as Gates and Höffler (2004) find the same pattern also for the other G7 countries. The reverse relationship, aid as a determinant of voting, has been investigated by a sizeable literature summarized in Dreher and Sturm (2006). According to their survey, empirical findings have remained inconclusive. Some studies, including Kato (1969), Kegley and Hook (1991), Sexton and Decker (1992) as well as Morey and Lai (2003), conclude that aid is ineffective in influencing the voting behavior of recipients. By contrast, Bernstein and Alpert (1971), Rai (1972, 1980), Wittkopf (1973), Lundborg (1998) and Wang (1999) find the expected positive relation between bilateral aid and voting similarity. According to Rai (1980), there is a stronger coincidence of votes cast by the United States and Latin American countries, compared with votes cast by UN members from Africa, the Middle East and South Asia. Considering votes (by 65 countries in 1984-1993) that were classified by the US State Department as being important, Wang (1999) finds that changes in the level of US aid significantly increase voting coincidence, while the coefficient of the level itself is insignificant. Lundborg (1998) focuses on relative support for the United States and the Soviet Union in 1948-1979. His simultaneous regressions reveal that (i) both donors employed aid to stimulate international political support, and (ii) aid recipients allocated their support to stimulate aid. Dreher et al. (2008) use disaggregated aid data to account for the fact that various forms of aid may differ in their ability to induce political support by recipients. They obtain strong evidence that US general budget support and untied grants buy voting compliance in the UNGA.

Donors other than the United States have hardly been investigated in this strand of the literature. An early exception is Wittkopf (1973), who covers all member countries of the OECD's Development Assistance Committee (DAC) and the Soviet Bloc for the years 1962

\footnotetext{
${ }^{9}$ See McKeown (2009) for an illustrative study on how U.S. decision-makers exerted control over multilateral organizations.
} 
and 1967. His correlation analysis shows, however, that only US aid is significantly associated with voting patterns. Dreher and Sturm (2006) analyze whether G7 donors employ financial assistance provided by the IMF and the World Bank to change the UN voting behavior of developing countries. They use panel data for 188 recipient countries over the 1970-2002 period. Applying Extreme Bounds Analysis to test for the robustness of results, they find that countries receiving financial support from the IMF and the World Bank tend to vote more frequently in line with G7 countries. By contrast, bilateral aid by G7 donors is not robustly related to UN voting behavior. Kilby (2006) reports that voting alignment with Japan in the UNGA reduces funding by the Asian Development Bank in the 1968-1986 period but increases funding in the more recent period from 1987-2002. According to Kilby (2009a), who uses data on World Bank disbursements over the years 1984-2005 for almost 100 countries, the World Bank enforces its structural adjustment conditions less rigorously in countries voting in line with the United States in the UN. Kilby (2009b) also links UNGA voting to World Bank funds and finds that UN voting alignment partly reflects vote buying, and partly reflects broader alliances.

In accordance with previous literature, the amount of aid received by a country is included in our empirical analysis as a determinant of voting. In addition, countries less dependent on aid are less likely to be bribed. High income, access to natural resources or military strength are among the factors that decide whether countries can afford to vote according to their own preferences.

In the UNGA, the same actors vote repeatedly over a large number of issues. Votes may be traded between members which gives rise to coalitions or voting blocs stable over time. As an example, coordination at the UN is regarded as part of the EU's Common Foreign and Security Policy (see Luif 2003). EU member states are called on to adopt common positions-when there is disagreement among EU members, the casting of opposing votes should be avoided. This gives room for trading of votes: members opposing a particular position abstain from the vote to present a common EU position in the UNGA and expect other members to do the same in votes on other areas where consensus is lacking. Even where formal coordination does not take place, countries may form voting coalitions informally if the promise that insincere voting behavior will be rewarded is credible.

According to Hurwitz (1975), voting cohesion is clearly above average on human rights issues. The differences among EU countries are marginal for these questions (Luif 2003, Graph 2 and Table 5). Previous EU candidates have also quickly adjusted to the EU position (Luif 2003). Clearly, the higher the stability and the smaller the number of dissenters, the smaller is the expected correlation between a country's issue interests and its voting behavior. Statistically, the fact that voting may be correlated between countries and issues can introduce bias if it is not controlled for. If unobserved factors that are common within a particular voting bloc correlate with variables relating to the country, the impact of the latter on voting behavior may be spurious. We deal with this problem in the next section.

\section{The empirical model}

In this section, we develop the empirical model for explaining voting behavior in the UNGA. As the dependent variable, we use voting behavior recoded in the way described in the second section and displayed in Table 3. The dependent variable can, therefore, take three outcomes: a vote in favor of the protection of human rights, a vote against, and abstention. We exclude non-participation. As Table 3 shows, the percentage of non-participations is relatively low. Hence, the potential bias introduced by self-selection into the pool of voters 
is small. Moreover, self-selection is likely to be exogenous to the particular issue voted on. In almost all cases, non-participations are not absences at particular votes, but relate to an entire session of the UNGA. Hence, it is reasonable to disregard any possible selectivity problems. $^{10}$

Since the outcome variable has an ordered structure, we use the ordered probit model as an estimator. Abstentions are thus regarded as an option between 'Yes' and 'No.' This is consistent with the idea that abstentions arise due to indifference between the alternatives voted on. Alternatively, voting "No" and abstaining may be very close substitutes. This would be true if they both signify rejection of a resolution. In the empirical literature on the UNGA, there is substantial disagreement on how to treat abstentions. For instance, Volgy et al. (2003) and Voeten (2000) take abstentions to be a softer form of voting "No" and merge these alternatives. By contrast, Wittkopf (1973), Sexton and Decker (1992) and Barro and Lee (2005) treat all alternatives as separate, such that two countries are taken as voting together if both vote "Yes," both vote "No," both abstain or both do not participate. Russett (1967), Rai (1972), Thacker (1999) and Luif (2003), among others, use cardinal measures of voting, such that, for instance, a vote in favor is assigned the number 1, a vote against is coded as 0 , and an abstention as 0.5 .

These coding procedures are chosen ad hoc and their empirical validity remains untested. The reason is that the studies mentioned either aggregate across votes or require a dependent variable coded in a particular way, such as a cardinal variable, and subsequent empirical procedures do not allow one to nest the coding procedure chosen within a more general framework. By using the ordered probit model, we avoid ad hoc cardinalization and are able to test whether "No" and abstention are different categories by a likelihood ratio test. This consists in testing the restriction that the thresholds between "Yes" and "Abstention" and "Abstention" and "No" can be collapsed, so that a bivariate probit is appropriate.

We estimate models with and without country fixed effects (i.e., including country dummies). ${ }^{11}$ The independent variables can be grouped into several categories. First, we include measures relating to the countries' human rights situation to proxy for the instrumental interest in the vote. Second, several political variables, such as political freedoms, democracy and interest groups, are included. These variables relate less to the instrumental motive since resolutions typically refer to individual human rights as opposed to political participation rights. Third, aid and resources are the main variables to check whether countries bend or resist to pressure to vote for UNGA resolutions. Fourth, we introduce a peer group variable to capture the dependence of voting across countries. Summary statistics of all independent variables are contained in the Appendix.

As our main measure of human rights, we follow the definition of citizens' human rights in Cingranelli and Richards (1999). Their Human Rights Dataset (CIRI, Cingranelli and Richards 2006) provides quantitative information on government respect for 13 internationally recognized human rights, on an annual basis and for almost all countries of the world. Cingranelli and Richards focus on actual human rights-related actions of governments, including all government agents such as police and military. Their database draws from two sources, the U.S. Department of State's Country Reports on Human Rights Practices, and from Amnesty International's Amnesty International Report, offering detailed descriptions of human rights practices.

\footnotetext{
${ }^{10}$ Boockmann (2006) uses a correction for selectivity in an ordered probit analysis of voting data for ILO committees where selectivity is more of a problem.

${ }^{11}$ Note that the incidental parameters problem is not an issue here, because the number of countries is fixed while the asymptotics for the number of votes tend to infinity.
} 
The relevant composite index refers to physical integrity rights-it is the additive of torture, extrajudicial killings, political imprisonments, and disappearances, on a scale from 0 to 8 (so-called "negative rights"). Each variable is coded on an ordinal scale, ranging between 0 and 2, where higher values reflect better ratings in the respective human rights dimension. ${ }^{12}$ To avoid an excess of parameters, we aggregate the $0-8$ CIRI scale to a four-point scale in estimation. ${ }^{13}$ The resulting variable is denoted PHYSINT. The implied restrictions were accepted using a Wald test (p-value: 0.140 in our first specification).

As a second measure of human rights practices, we employ the Political Terror Scale (PTS) to capture domestic political terror, including issues such as: imprisonments, tortures, rule of law, security, disappearances and executions. The PTS index was codified by Cornett and Gibney (2003), measuring states' human rights records on a yearly basis. The PTS is based on a five-point interval scale, with higher values implying greater political terror. We include the variable without further adjustments (and label it PTS). One problem with these data is that they do not necessarily relate to states' human rights practices but are also influenced by actions of non-state actors. By comparison with the CIRI data, we observe some striking differences. In particular, the democratization and ensuing improvement of human rights in Eastern Europe shows in a huge increase in the CIRI series, but is hardly noticeable in the PTS data. Hence, these two data sources can be used as complementary measures.

Apart from physical integrity rights, participation (empowerment) rights may influence voting on human rights, but for a different reason. Participation rights are less frequently included as an object in UNGA resolutions. They are, therefore, less valuable as proxies for the instrumental motive. However, participation rights may allow groups in society, such as minorities, to articulate political demands and urge government to change their human rights practices. It is well known that more democratic countries are more likely to enter human rights agreements (e.g., Hathaway 2002; Landmann 2005). ${ }^{14}$ Since this channel of influence differs from the instrumental motive, we include measures of participation and physical integrity rights in the same specification. Participation rights are measured by another composite indicator proposed in Cingranelli and Richards (1999) and Richards et al. (2001). It refers to empowerment rights and comprises the freedom of movements, freedom of speech, workers' rights, political participation, and freedom of religion indicators, ranging from 0 to 10 . The scale is again aggregated to four categories for estimation (EM$P O W E R)$. An alternative measure is a dummy variable for democracies (DEMOC), taken from Polity IV.

In addition, human rights NGOs and other interest groups may increase pressure on governments to change the human rights situation. Following Neumayer (2005), we use the number of NGOs being represented in a country to measure interest groups pressure $(N G O)$.

\footnotetext{
${ }^{12}$ For example, on the "Torture" indicator, "a score of 0 indicates that torture was practiced frequently in a given year; a score of 1 indicates that torture was practiced occasionally; and a score of 2 indicates that torture did not occur in a given year." (CIRI documentation, http://ciri.binghamton.edu/documentation/ ciri_variables_short_descriptions.pdf, accessed October 2, 2009). The scoring of the ordinal indices rests on events-based criteria. As Cingranelli and Richards (1999) show employing Mokken Scale Analysis, the government decision to violate individual rights is unidimensional. The indicators can thus be aggregated to overall indices by simply adding the individual dimensions.

${ }^{13}$ All categories of the original variable below 4 were aggregated to a new category; the remaining categories were joined to groups of two and the highest category was used without recoding.

${ }^{14}$ However, not all dictatorships act alike. As Vreeland (2008) shows, dictatorships that practice torture are more likely to accede to the UN convention against torture.
} 
As we are specifically interested in issues related to human rights, we acquired the number of NGOs working in this particular area from the Union of International Associations (2000).

The development aid DEVAID variable comprises official development aid per capita of the recipient country and is taken from the World Bank Development Indicators (WDI 2006). We use a composite indicator NATCAP of national capability that is a measure of power based upon six indicators: military expenditure, military personnel, energy consumption, iron and steel production, urban population, and total population (Singer et al. 1972). According to the analysis in Dreher and Sturm (2006), countries which score high on this composite indicator and thus depend less on foreign relationships vote in a more autonomous manner in the UNGA. As a second proxy for a country's ability to resist pressure, we employ its GDP per capita, taken from the Penn World Tables (Summers and Heston 1991). In addition, we use the number of military conflicts as a determinant of human rights voting (CONFLICTS). As a consequence of military conflicts, governments may expect to be condemned for poor human rights practices in the future, giving these governments a reason to vote against human rights resolutions.

Finally, several sets of dummy variables are included to control for legal, political, cultural or religious impacts on UN voting which are not captured otherwise. They indicate region, the main religious affiliation of the population, legal origin, and OECD and Warsaw Pact membership and are included in the specifications not containing country fixed effects.

Some other plausible explanatory variables were tried but not included in the final specifications: The general-to-specific approach and robustness tests employing Extreme Bounds Analysis in Dreher et al. (2006) suggest a number of further variables as significant predictors of a country's level of physical integrity rights, such as the age of a country's democracy or its population. ${ }^{15}$ Dreher et al. (2007) show that the number of terror events significantly reduces the level of human rights in a country. In addition to these variables we also included membership in the UN Commission on Human Rights as a further explanatory variable to test for possible links between the UNCHR and the UNGA. All of these variables, however, were found to be completely insignificant and, hence, they were excluded from the estimations reported below.

A difficult problem is the presence of voting coalitions. This means that voting is not conditionally independent, i.e., the error terms of our regressions are not independently and identically distributed. We correct for this by including a variable indicating voting in a "peer group" of similar countries. Peer group variables have been used in a number of other studies of international organizations, such as the IMF (Simmons 2000) or the ILO (Chau and Kanbur 2002). Peer groups are taken to be countries within the same world region, as defined by the World Bank. The variable $(P G)$ is constructed as the proportion of countries voting in favor of human rights (using the same recoding as for the dependent variable) minus the proportion voting against. ${ }^{16}$ The peer group variable captures both the mutual dependence of voting due to regional coalitions, as well as the influence of common unobserved factors within the peer group. Its coefficient should, therefore, not be interpreted as a measure of mutual causal influence. As we are interested in the amount of bias that may arise due to the neglect of dependence in voting, we estimate all specifications with and without the peer group variable. There is a potential problem that endogeneity due to unobserved factors may bias not only the estimate of the peer group variable itself, but also the other coefficients.

\footnotetext{
${ }^{15}$ See also Bjørnskov (2008).

${ }^{16}$ We use the difference between votes in favor and votes against to allow for a different impact of abstentions and votes against on the peer group variable.
} 
While we cannot rule this out, including the peer group variable still helps to substantiate (or reject) the sensitivity of the coefficients with respect to the assumption of cross-sectional independence of the error terms.

The data used for estimation consist of the 173 roll-call votes between 1980 and 2002 displayed in Table 1. Due to the lack of information on independent variables, there remain only 13,201 observations of the 28,569 voting decisions in the data. In 5,348 cases, this is due to the lack of human rights information-the other losses occur due to missing information on GDP, development aid and other variables. All in all, the loss of observations and, hence, the degree of selectivity is not larger than in comparable cross-country-time-series studies.

\section{Estimation results}

A likelihood ratio test of the binary versus the ordered probit model rejects the former at very high levels of significance. Therefore, we conclude that countries do make a difference between the alternative of voting against and abstaining, and aggregating both choices into one should be avoided. Hence, we report results only from the ordered probit.

Table 4 displays estimation results using the CIRI measure of human rights. Table 5 uses the PTS data. In the latter case, the random effects model ran into numerical difficulties and we display pooled estimation results (with standard errors adjusted for repeated observations by country) instead. The random effects specification is preferred to a simple pooled specification but is rejected by a Hausman test. Hence, we will discuss results only from the fixed effects model here. However, the results from both models do not differ much qualitatively and quantitatively - the main effect being larger standard errors in the fixed effects case. The outcome variable is coded such that a vote in favor of human rights takes the lowest and a vote against the highest value. Hence, positive coefficients mean that the independent variable induces countries to take a negative stance towards human rights resolutions.

Columns 1 and 2 of Table 4 contain coefficient estimates for the random and fixed effects models without the peer group variables. The coefficients of the physical integrity (PHYSINT) and empowerment rights (EMPOWER) dummies are estimates of the difference in voting behavior relative to a reference category, the countries with most extensive rights. Both random and fixed effect estimations suggest a clear relation between the human rights situation and voting: Governments granting less physical integrity rights are significantly ${ }^{17}$ more likely to oppose UNGA human rights resolutions than countries in the category with the highest level of rights (the omitted group). The impact is monotonic and differs significantly between countries in the highest and the two lowest categories; the group of dummies is jointly significant at the $1 \%$ level. Based on the coefficient estimates, the marginal effects of the independent variables on the probability of choosing a particular alternative may be calculated. The effect of being in the worst rather than the best human rights category on the probability of voting for human rights is $-13.1 \%$ according to the fixed effects model, while the effect of voting against is $10.9 \%$. Thus, the model predicts that if the worst human rights offenders moved to the best human rights category, this would change their voting behavior in one out of eight or nine voting decisions.

Empowerment rights exert a less clear influence on voting decisions, and the marginal effects are far smaller and not monotonic in the fixed effects estimation. Countries engaged

${ }^{17}$ Unless otherwise noted, significance refers to the $5 \%$ level. 
Table 4 Ordered Probit Estimation using CIRI data

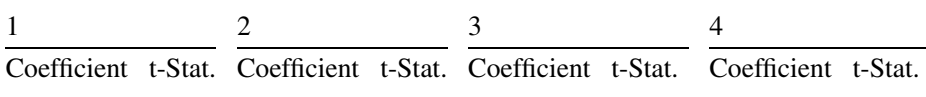

Physical Integrity Rights (PHYSINT, baseline: $4=$ highest)

$\begin{array}{lrrrrrrrr}1 \text { (lowest) } & * * * 0.193 & 3.49 & * * * 0.323 & 3.46 & 0.056 & 0.74 & 0.128 & 1.13 \\ 2 & * 0.091 & 1.82 & * * * 0.200 & 2.44 & -0.020 & -0.28 & 0.051 & 0.53 \\ 3 & 0.026 & 0.57 & 0.074 & 1.02 & -0.026 & -0.43 & -0.011 & -0.16\end{array}$

Empowerment Rights (EMPOWER, baseline: 4 = highest)

$\begin{array}{lrlllllll}1 \text { (lowest) } & * * 0.119 & 2.17 & 0.083 & 0.71 & * * * 0.412 & 5.26 & * * * 0.456 & 3.22 \\ 2 & 0.056 & 1.13 & 0.035 & 0.38 & * * * 0.317 & 4.60 & * * * 0.320 & 2.73 \\ 3 & 0.055 & 1.30 & 0.061 & 0.88 & 0.093 & 1.57 & 0.103 & 1.19\end{array}$

Military Conflicts (CONFLICTS)

\begin{tabular}{|c|c|c|c|c|c|c|c|c|}
\hline 1 & -0.009 & -0.30 & -0.019 & -0.48 & 0.022 & 0.54 & -0.009 & -0.16 \\
\hline 2 or 3 & **0.096 & 2.28 & $* 0.105$ & 1.71 & $* * * 0.222$ & 3.95 & ${ }^{* *} 0.215$ & 2.13 \\
\hline more than 3 & 0.102 & 1.23 & 0.036 & 0.33 & $* * * 0.321$ & 3.11 & 0.279 & 1.10 \\
\hline Real GDP p.c. & $* * *-0.043$ & -7.31 & $* * *-0.077$ & -2.94 & $* * *-0.083$ & -10.14 & $* *-0.086$ & -2.29 \\
\hline Capacity $(N A T C A P)$ & $* * * 0.095$ & 6.90 & $* 0.440$ & 1.75 & $* * * 0.212$ & 10.46 & ***0.951 & 2.72 \\
\hline Interest Groups $(N G O)$ & $* * *-0.003$ & -3.47 & 0.001 & 0.17 & $* * *-0.008$ & -4.99 & $*-0.015$ & -1.81 \\
\hline Aid p.c. $(D E V A I D)$ & *** -0.007 & -3.59 & -0.003 & -1.30 & $* * *-0.007$ & -2.34 & -0.001 & -0.25 \\
\hline Peergroup Voting $(P G)$ & & & & & $* * *-2.696$ & -80.82 & $* * *-2.727$ & -15.89 \\
\hline Number of obs. & \multicolumn{2}{|c|}{13239} & \multicolumn{2}{|c|}{13239} & \multicolumn{2}{|c|}{13239} & \multicolumn{2}{|c|}{13239} \\
\hline Log Likelihood at start & \multicolumn{2}{|c|}{-12027.131} & \multicolumn{2}{|c|}{-12027.131} & \multicolumn{2}{|c|}{-12027.131} & \multicolumn{2}{|c|}{-12027.131} \\
\hline Log Likelihood final & \multirow{2}{*}{\multicolumn{2}{|c|}{-11475.113}} & \multirow{2}{*}{\multicolumn{2}{|c|}{-11395.632}} & \multirow{2}{*}{\multicolumn{2}{|c|}{-5675.293}} & \multicolumn{2}{|c|}{-5446.141} \\
\hline Fixed or Random & & & & & & & & \\
\hline Effects & \multicolumn{2}{|c|}{ Random } & \multicolumn{2}{|c|}{ Fixed } & \multicolumn{2}{|c|}{ Random } & \multicolumn{2}{|c|}{ Fixed } \\
\hline Test of rho $=0$ & \multicolumn{2}{|c|}{0.001} & & & \multicolumn{2}{|c|}{0.001} & & \\
\hline Test of No $=$ Abst. & \multicolumn{2}{|c|}{0.000} & \multicolumn{2}{|c|}{0.000} & \multicolumn{2}{|c|}{0.000} & \multicolumn{2}{|c|}{0.000} \\
\hline Hausman Test & & & \multicolumn{2}{|c|}{0.005} & & & \multicolumn{2}{|c|}{0.138} \\
\hline Joint Sign. of HR & \multicolumn{2}{|c|}{0.000} & \multicolumn{2}{|c|}{0.002} & \multicolumn{2}{|c|}{0.866} & \multicolumn{2}{|c|}{0.514} \\
\hline
\end{tabular}

Note: Period, region, religion, legal tradition, OECD and Warsaw Pact membership dummies included. $* * *, * *$ and ${ }^{*}$ symbolize significance at the 1,5 and $10 \%$ levels

in two or three military conflicts in the year of voting tend to vote against human rights standards as compared to the reference group. The effect is significant at the $5 \%$ level in the random effects model and at the $10 \%$ level if fixed effects are included. There is no significant effect for countries with even more conflicts. However, the number of countries in this group is small. The effect of the number of human rights interest groups operating in the country has the expected negative sign (more NGOs reduce the propensity to vote against human rights), but becomes insignificant once fixed effects are included. Therefore, we conclude that the random effects estimator of this coefficient is biased due to the correlation between interest groups and country-specific unobservables. The same appears to be true for development aid. Countries' capacity as measured by the Singer et al. (1972) index has a positive impact, which remains significant throughout the different estimations. The 
Table 5 Ordered Probit Estimation using PTS data

\begin{tabular}{|c|c|c|c|}
\hline 1 & 2 & 3 & 4 \\
\hline$\overline{\text { Coefficient } \mathrm{t} \text {-Stat. }}$ & $\overline{\text { Coefficient } \mathrm{t} \text {-Stat. }}$ & Coefficient t-Stat. & Coefficient t-Stat. \\
\hline
\end{tabular}

Political Terror scales (PTS, baseline: $1=$ lowest)

\begin{tabular}{|c|c|c|c|c|c|c|c|c|}
\hline 2 & 0.032 & 0.55 & 0.059 & 0.75 & 0.073 & 0.87 & 0.043 & 0.45 \\
\hline 3 & $* 0.117$ & 1.72 & $* * 0.196$ & 2.23 & 0.080 & 0.77 & 0.101 & 0.86 \\
\hline 4 & $* * * 0.195$ & 2.39 & $* 0.214$ & 1.95 & $* 0.225$ & 1.91 & 0.141 & 1.04 \\
\hline (highest) & 0.138 & 1.55 & 0.137 & 1.12 & 0.278 & 1.45 & 0.187 & 1.02 \\
\hline $\begin{array}{l}\text { Democracy } \\
(D E M O C, 1=\text { yes })\end{array}$ & $* * *-0.025$ & -3.50 & $* * *-0.041$ & -3.15 & $* * *-0.066$ & -6.10 & $* * *-0.090$ & -5.28 \\
\hline itary Conflicts (CON & VFLICTS) & & & & & & & \\
\hline 1 & 0.005 & 0.15 & -0.014 & -0.36 & 0.026 & 0.50 & -0.011 & -0.21 \\
\hline or 3 & $* 0.081$ & 1.69 & 0.078 & 1.30 & $* * 0.161$ & 2.18 & $* 0.163$ & 1.66 \\
\hline more than 3 & $* 0.188$ & 1.87 & 0.041 & 0.40 & **0.409 & 2.11 & 0.275 & 1.06 \\
\hline eal GDP p.c. & $* * *-0.033$ & -4.10 & $* * *-0.071$ & -2.78 & $* * *-0.059$ & -4.64 & $* * *-0.091$ & -2.36 \\
\hline Capacity (NATCAP) & $* * * 0.084$ & 6.05 & $* * * 0.628$ & 3.04 & $* * * 0.157$ & 5.64 & $* * * 1.034$ & 2.56 \\
\hline Interest Groups (NGO) & $* * *-0.004$ & -3.63 & 0.004 & 0.84 & $* * *-0.008$ & -3.80 & -0.010 & -1.18 \\
\hline Aid p.c. $(D E V A I D)$ & $* * *-0.009$ & -3.93 & -0.002 & -0.78 & $* * *-0.017$ & -4.71 & -0.001 & -0.22 \\
\hline Peergroup Voting $(P G)$ & & & & & $* * *-2.605$ & -15.94 & $* * *-2.705$ & -14.94 \\
\hline Number of obs. & \multicolumn{2}{|c|}{12403} & \multicolumn{2}{|c|}{12403} & \multicolumn{2}{|c|}{12403} & \multicolumn{2}{|c|}{12403} \\
\hline Log Likelihood at start & \multicolumn{2}{|c|}{-12484.552} & \multicolumn{2}{|c|}{-12484.552} & \multicolumn{2}{|c|}{-12484.552} & \multicolumn{2}{|c|}{-12484.552} \\
\hline Log Likelihood final & \multicolumn{2}{|c|}{-10671.105} & \multicolumn{2}{|c|}{-10566.705} & \multicolumn{2}{|c|}{-5303.806} & \multicolumn{2}{|c|}{-5077.517} \\
\hline Fixed Effects & \multicolumn{2}{|c|}{ None } & \multicolumn{2}{|c|}{ Fixed } & \multicolumn{2}{|c|}{ None } & \multicolumn{2}{|c|}{ Fixed } \\
\hline Test of No $=$ Abst. & \multicolumn{2}{|c|}{0.000} & \multicolumn{2}{|c|}{0.000} & \multicolumn{2}{|c|}{0.000} & \multicolumn{2}{|c|}{0.000} \\
\hline Joint Sign. of HR & \multicolumn{2}{|c|}{0.045} & \multicolumn{2}{|c|}{0.035} & \multicolumn{2}{|c|}{0.227} & \multicolumn{2}{|c|}{0.791} \\
\hline
\end{tabular}

Note: Period, region, religion, legal tradition, OECD and Warsaw Pact membership dummies included. $* * *, * *$ and ${ }^{*}$ symbolize significance at the 1,5 and $10 \%$ levels

interpretation is that countries scoring higher on this index have more leeway in their foreign policies and are less forced to adopt positions shared mainly by Western industrialized democracies. By contrast, richer countries (as measured by real GDP per capita) vote more often in favor of human rights. This is likely to be due to (time-) variation in development and wealth not captured by the region and OECD dummies.

A dummy variable indicating years after 1990 shows that voting against human rights has become less frequent in the second half of our observation period. The marginal effects are $14.2 \%$ for voting in favor and $-11.1 \%$ for voting against. In a further specification, we split the data into two time intervals and performed separate estimations. However, little evidence was found for a change in the coefficients of the determinants of voting. ${ }^{18}$

\footnotetext{
${ }^{18}$ These results are available on request. The conclusions from including country dummies remain unchanged when peer group effects are included (see below). If they are omitted, the effect of human rights variables on voting is reduced as compared to our preferred specification.
} 
In the third and fourth columns, we present identical results but with the peer group variable included. The variable is highly significant and results in a huge improvement in the likelihood function. Thus, including this variable represents a massive change in the specification. Nevertheless, many coefficients prove to be stable compared to the results without peer groups. In the fixed effects specification, the sizes of the coefficients generally increase and the number of interest groups becomes (marginally) significant. The empowerment rights dummies also increase in magnitude and categories 1 and 2 are now statistically significant. A most notable change, however, affects the impact of physical integrity rights. These variables are now much reduced in magnitude and cease to be statistically significant.

The change for the human rights variable suggests that the effects estimated under the assumption of conditional independence of the errors are biased. The coefficients are all insignificant, and the implied marginal effects are in the range of zero to 5\%. Substantively, this suggests that countries' individual human rights situations do not induce them to support or oppose human rights resolutions. Rather, regional groups of countries with different average levels of human rights vote together in such a way that regions with better human rights generally adopt pro-human rights voting policies. In other words, while the results do not exclude an impact of human rights on voting, the effect does not take place at the country level. Human rights resolutions are not evaluated by each individual country against the background of its own human rights policies.

Next, we consider alternative measures for physical integrity and democratic participation rights (see Table 5). Using again the fixed effects estimation results as the preferred ones, we observe few changes as compared to Table 4. In particular, the human rights variables, here taken from the PTS data, are jointly significant and indicate the expected direction of the influence in the estimations without peer groups, but become insignificant once peer group voting is included. We also find that the democracy dummy increases in magnitude and significance, similar to the empowerment dummies in Table 4. The similarity of the estimates from Tables 4 and 5 show that the results are not an artifact of the measurement of human rights and democratic political participation and reinforce our confidence in our conclusions.

Tables 6 and 7 replicate the analysis including dummies for each year, which are jointly significant at the $1 \%$ level in all specifications. ${ }^{19}$ As can be seen from the tables, the main results are not affected by the inclusion of the time dummies. For the results shown in Table 6 , both empowerment rights and physical integrity rights affect voting at the $1 \%$ level of significance in the random effects and the fixed effects specifications without peer group voting (joint significance test) ${ }^{20}$ If peer group voting is included, empowerment rights remain significant but physical integrity rights become insignificant. ${ }^{21}$ In contrast to our previous results, Table 7 shows that a country's human rights situation as measured by the political terror scale does not significantly affect a country's voting behavior. The political terror scales are jointly insignificant even without including peer group voting. ${ }^{22}$

One might argue that countries improve their human rights situations in order to be admitted to coalitions with other countries, which is correlated with the voting record. To control

\footnotetext{
${ }^{19}$ The reason for not including them in our first set of results is that there may be an incidental parameter problem when we use both time and country dummies. However, it should be noted that there are multiple observations per country-year in our data, which alleviates the problem.

${ }^{20}$ The $\chi^{2}$ statistics are 22.4 and 17.4 for the random effects model and 27.2 and 22.5 for the fixed effects model. The different categories of physical integrity rights are mostly insignificant individually.

${ }^{21}$ With $\chi^{2}$ statistics of 45.3 and 3.2 for the random effects model and 49.9 and 5.9 for the fixed effects model.

${ }^{22}$ The $\chi^{2}$ statistics are 8.9 and 4.7 in the random effects and fixed effects models.
} 
Table 6 Ordered Probit Estimation using CIRI data (including year dummies)

\begin{tabular}{|c|c|}
\hline 1 & 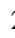 \\
\hline
\end{tabular}

Physical Integrity Rights (PHYSINT, baseline: $4=$ highest)

$\begin{array}{lrrrrrrrr}1 \text { (lowest) } & 0.079 & 1.40 & * 0.146 & 1.70 & 0.025 & 0.33 & 0.105 & 0.92 \\ 2 & -0.016 & -0.32 & 0.043 & 0.61 & -0.046 & -0.68 & 0.030 & 0.32 \\ 3 & *-0.077 & -1.67 & -0.059 & -0.95 & -0.045 & -0.75 & -0.033 & -0.46\end{array}$

Empowerment Rights (EMPOWER, baseline: 4 = highest)

$\begin{array}{lrrrrrrrr}1 \text { (lowest) } & * * * 0.230 & 4.06 & * * * 0.303 & 2.82 & * * * 0.450 & 5.58 & * * * 0.526 & 3.61 \\ 2 & * * * 0.192 & 3.70 & * * * 0.232 & 2.69 & * * * 0.337 & 4.62 & * * * 0.373 & 3.11 \\ 3 & 0.064 & 1.44 & 0.081 & 1.38 & 0.090 & 1.46 & 0.115 & 1.32\end{array}$

Military Conflicts (CONFLICTS)

\begin{tabular}{|c|c|c|c|c|c|c|c|c|}
\hline 1 & 0.009 & 0.30 & -0.006 & -0.19 & 0.016 & 0.38 & -0.009 & -0.17 \\
\hline 2 or 3 & $* * * 0.107$ & 2.49 & $* 0.110$ & 1.82 & $* * * 0.211$ & 3.75 & $* * 0.215$ & 2.10 \\
\hline more than 3 & 0.092 & 1.09 & 0.055 & 0.47 & $* * * 0.279$ & 2.66 & 0.265 & 1.05 \\
\hline Real GDP p.c. & $* * *-0.047$ & -7.50 & $* * *-0.074$ & -2.99 & $* * *-0.085$ & -9.12 & $* *-0.085$ & -2.27 \\
\hline Capacity $(N A T C A P)$ & $* * * 0.112$ & 7.58 & $* * * 0.681$ & 2.87 & $* * * 0.204$ & 9.18 & $* * * 1.001$ & 2.85 \\
\hline Interest Groups $(N G O)$ & $* * *-0.006$ & -5.23 & $* * *-0.026$ & -3.15 & $* * *-0.008$ & -5.47 & $*-0.022$ & -1.83 \\
\hline Aid p.c. $(D E V A I D)$ & $* * *-0.005$ & -2.31 & 0.001 & 0.53 & -0.004 & -1.10 & 0.001 & 0.14 \\
\hline Peergroup Voting $(P G)$ & & & & & $* * *-2.700$ & 79.63 & $* * *-2.726$ & 16.00 \\
\hline Number of obs. & \multicolumn{2}{|c|}{13239} & \multicolumn{2}{|c|}{13239} & \multicolumn{2}{|c|}{13239} & \multicolumn{2}{|c|}{13239} \\
\hline Log Likelihood at start & \multicolumn{2}{|c|}{-12027.131} & \multicolumn{2}{|c|}{-12027.131} & \multicolumn{2}{|c|}{-12027.131} & \multicolumn{2}{|c|}{-12027.131} \\
\hline Log Likelihood final & \multicolumn{2}{|c|}{-11154.401} & \multicolumn{2}{|c|}{-11058.601} & \multicolumn{2}{|c|}{-5560.158} & \multicolumn{2}{|c|}{-5430.469} \\
\hline Fixed or Random Effects & \multicolumn{2}{|c|}{ Random } & \multicolumn{2}{|c|}{ Fixed } & \multicolumn{2}{|c|}{ Random } & \multicolumn{2}{|c|}{ Fixed } \\
\hline Test of rho $=0$ & \multicolumn{2}{|c|}{0.001} & \multicolumn{6}{|c|}{0.000} \\
\hline Test of No $=$ Abst. & \multicolumn{2}{|c|}{0.000} & \multicolumn{2}{|c|}{0.000} & \multicolumn{2}{|c|}{0.000} & \multicolumn{2}{|c|}{0.000} \\
\hline Hausman Test & \multicolumn{4}{|c|}{0.000} & & & \multicolumn{2}{|c|}{$\mathrm{n} / \mathrm{a}$} \\
\hline Joint Sign. of HR & \multicolumn{2}{|c|}{0.001} & \multicolumn{2}{|c|}{0.000} & \multicolumn{2}{|c|}{0.367} & \multicolumn{2}{|c|}{0.117} \\
\hline
\end{tabular}

Note: Region, religion, legal tradition, OECD, Warsaw Pact membership, and year dummies included. ***, ** and ${ }^{*}$ symbolize significance at the 1,5 and $10 \%$ levels

for the potential endogeneity of human rights, we thus replicate the analysis using the system GMM estimator as suggested by Arellano and Bond (1991), Arellano and Bover (1995) and Blundell and Bond (1998). To do so, we define an index variable as a new dependent variable. First, we assign values $-1,0$ and 1 to votes against, abstention and votes in favor. Second, we aggregate these data at the country-year level. Thus, the dependent variable is the average of the cardinal voting variable and ranges between -1 and 1 . Only a small proportion (14\%) of observations is at the corner values. Hence, we feel justified in using a linear model. As we assume this variable to be rather persistent over time, we include the lagged dependent variable as additional regressor.

The dynamic panel GMM estimator exploits an assumption about the initial conditions to obtain moment conditions that remain informative even for persistent data. It is considered most appropriate in the presence of endogenous regressors. Results are based on the two- 
Table 7 Ordered Probit Estimation using PTS data (including year dummies)

\begin{tabular}{|c|c|c|c|}
\hline 1 & 2 & 3 & 4 \\
\hline Coefficient $\mathrm{t}$-Stat. & $\overline{\text { Coefficient t-Stat. }}$ & Coefficient t-Stat. & Coefficient t-Stat. \\
\hline
\end{tabular}

Political Terror scales $(P T S$, baseline: $1=$ lowest $)$

\begin{tabular}{|c|c|c|c|c|c|c|c|c|}
\hline 2 & -0.007 & -0.13 & 0.003 & 0.04 & 0.073 & 0.87 & 0.039 & 0.42 \\
\hline 3 & 0.051 & 0.79 & 0.082 & 1.13 & 0.077 & 0.73 & 0.087 & 0.74 \\
\hline 4 & $* * 0.152$ & 2.10 & 0.149 & 1.57 & $* * 0.230$ & 1.96 & 0.140 & 1.06 \\
\hline 5 (highest) & 0.102 & 1.12 & 0.087 & 0.81 & 0.260 & 1.34 & 0.165 & 0.90 \\
\hline $\begin{array}{l}\text { Democracy } \\
(D E M O C, 1=\text { yes })\end{array}$ & $* * *-0.032$ & -4.38 & 0.003 & 0.04 & $* * *-0.067$ & -6.15 & $* * *-0.094$ & -5.71 \\
\hline \multicolumn{9}{|c|}{ Military Conflicts (CONFLICTS) } \\
\hline 1 & 0.013 & 0.43 & -0.011 & -0.32 & 0.026 & 0.49 & -0.017 & -0.32 \\
\hline 2 or 3 & $* 0.083$ & 1.80 & 0.073 & 1.23 & $* * 0.162$ & 2.17 & 0.155 & 1.53 \\
\hline more than 3 & $* 0.188$ & 1.90 & 0.057 & 0.49 & $* * 0.408$ & 2.10 & 0.261 & 0.99 \\
\hline Real GDP p.c. & $* * *-0.036$ & -4.37 & $* * *-0.074$ & -2.91 & $* * *-0.059$ & -4.69 & $* * *-0.092$ & -2.39 \\
\hline Capacity $(N A T C A P)$ & $* * * 0.095$ & 6.34 & $* * * 0.817$ & 3.39 & $* * * 0.159$ & 5.61 & $* * * 1.059$ & 2.58 \\
\hline Interest Groups $(N G O)$ & $* * *-0.005$ & -4.17 & $* * *-0.021$ & -2.68 & $* * *-0.008$ & -3.75 & -0.016 & -1.32 \\
\hline Aid p.c. $(D E V A I D)$ & $* * *-0.008$ & -3.81 & 0.001 & 0.57 & $* * *-0.017$ & -4.61 & 0.000 & 0.08 \\
\hline Peergroup Voting $(P G)$ & & & & & $* * *-2.611$ & 16.22 & $* * *-2.707$ & 15.07 \\
\hline Number of obs. & \multicolumn{2}{|c|}{12409} & \multicolumn{2}{|c|}{12409} & \multicolumn{2}{|c|}{12409} & \multicolumn{2}{|c|}{12409} \\
\hline Log Likelihood at start & \multicolumn{2}{|c|}{-12491.720} & \multicolumn{2}{|c|}{-12491.720} & \multicolumn{2}{|c|}{-12491.720} & \multicolumn{2}{|c|}{-12491.720} \\
\hline Log Likelihood final & \multicolumn{2}{|c|}{-10384.976} & \multicolumn{2}{|c|}{-10266.139} & \multicolumn{2}{|c|}{-5295.939} & \multicolumn{2}{|c|}{-5069.541} \\
\hline Fixed Effects & \multicolumn{2}{|c|}{ None } & \multicolumn{2}{|c|}{ Fixed } & \multicolumn{2}{|c|}{ None } & \multicolumn{2}{|c|}{ Fixed } \\
\hline Test of $\mathrm{No}=$ Abst. & \multicolumn{2}{|c|}{0.000} & \multicolumn{2}{|c|}{0.000} & \multicolumn{2}{|c|}{0.000} & \multicolumn{2}{|c|}{0.000} \\
\hline Joint Sign. of HR & \multicolumn{2}{|c|}{0.064} & \multicolumn{2}{|c|}{0.324} & \multicolumn{2}{|c|}{0.213} & \multicolumn{2}{|c|}{0.818} \\
\hline
\end{tabular}

Note: Region, religion, legal tradition, OECD, Warsaw Pact membership, and year dummies included. ${ }^{* * *},{ }^{* *}$ and ${ }^{*}$ symbolize significance at the 1,5 and $10 \%$ levels

step estimator implemented by Roodman (2005) in Stata, including Windmeijer's (2005) finite sample correction. We apply the Sargan-Hansen test on the validity of the instruments used (amounting to a test for the exogeneity of the covariates) and the Arellano-Bond test of second order autocorrelation, which must be absent from the data in order for the estimator to be consistent. We treat the lagged dependent variable and our measures of human rights and empowerment rights as endogenous and all other variables as strictly exogenous. As before, we include time dummies in the regression. In order to minimize the number of instruments in the regressions we collapse the matrix of instruments as suggested in Roodman (2006).

Tables 8 and 9 show the results. The Sargan-Hansen test and the Arellano-Bond test do not reject the GMM specifications at conventional levels of significance. ${ }^{23}$ As can be seen, while the results for our covariates are generally weaker than in the estimations based on

\footnotetext{
${ }^{23}$ The exception is the final specification of Table 7, where the Sargan test rejects the instruments at the $10 \%$ level, but not at the $5 \%$ level of significance.
} 
Table 8 GMM Estimation using CIRI data

\begin{tabular}{|c|c|c|c|c|}
\hline & \multicolumn{2}{|l|}{1} & \multicolumn{2}{|l|}{2} \\
\hline & Coefficient & t-Stat. & Coefficient & t-Stat. \\
\hline Lagged dependent variable & $* * * 0.408$ & 4.59 & 0.327 & 3.52 \\
\hline \multicolumn{5}{|c|}{ Physical Integrity Rights (PHYSINT, baseline: 4 = highest) } \\
\hline 1 (lowest) & 0.078 & 0.75 & -0.071 & -0.88 \\
\hline 2 & 0.088 & 0.90 & -0.021 & -0.21 \\
\hline 3 & 0.246 & 0.91 & 0.140 & 0.50 \\
\hline
\end{tabular}

Empowerment Rights (EMPOWER, baseline: $4=$ highest)

$\begin{array}{lrrrr}1 \text { (lowest) } & 0.055 & 0.58 & 0.105 & 1.03 \\ 2 & * * * 0.233 & 3.25 & * * * 0.245 & 3.65 \\ 3 & 0.123 & 0.88 & 0.145 & 1.08\end{array}$

Military Conflicts (CONFLICTS)

\begin{tabular}{|c|c|c|c|c|}
\hline 1 & -0.007 & -0.34 & -0.015 & -0.78 \\
\hline 2 or 3 & 0.009 & 0.30 & -0.002 & -0.05 \\
\hline more than 3 & 0.032 & 0.40 & -0.042 & -0.69 \\
\hline Real GDP p.c. & $* 0.009$ & 1.65 & 0.005 & 0.81 \\
\hline Capacity $(N A T C A P)$ & $* * *-0.029$ & -2.97 & $* * *-0.025$ & -3.11 \\
\hline Interest Groups $(N G O)$ & 0.000 & 0.44 & 0.000 & 0.42 \\
\hline Aid p.c. $(D E V A I D)$ & 0.000 & -0.26 & 0.002 & 1.22 \\
\hline Peergroup Voting $(P G)$ & & & $* * * 0.724$ & 7.86 \\
\hline Number of obs. & \multicolumn{2}{|c|}{2022} & \multicolumn{2}{|c|}{2022} \\
\hline Number of instruments & \multicolumn{2}{|c|}{56} & \multicolumn{2}{|c|}{57} \\
\hline Arellano-Bond test for $\mathrm{AR}(2)$ & \multicolumn{2}{|c|}{0.459} & \multicolumn{2}{|c|}{0.399} \\
\hline Sargan test & \multicolumn{2}{|c|}{0.209} & \multicolumn{2}{|c|}{0.057} \\
\hline Hansen test & \multicolumn{2}{|c|}{0.136} & \multicolumn{2}{|c|}{0.188} \\
\hline
\end{tabular}

Note: OECD, Warsaw Pact membership, and year dummies included. Estimation based on annual data. $* * *, * *$ and ${ }^{*}$ symbolize significance at the 1,5 and $10 \%$ levels

individual voting decisions, the main results are in line with those reported above. While the dummies for empowerment rights are again jointly significant at the $1 \%$ level (with a $\chi^{2}$ statistic of 10.6 and 14.5 for columns 1 and 2 of Table 8), neither physical integrity rights (Table 8) nor the political terror scale (Table 9) affect voting behavior at conventional levels of significance if peer group voting is included. ${ }^{24}$ The peer-group voting variable remains significant at the $1 \%$ level.

\section{Conclusions}

In this paper, we have addressed whether countries' human rights situations influence voting on human rights resolutions at the United Nations General Assembly (UNGA). Our

${ }^{24}$ The $\chi^{2}$ values are 1.8 and 2.0 for Table 7 and 13.0 and 4.1 for Table 8 . 
Table 9 GMM Estimation using PTS data

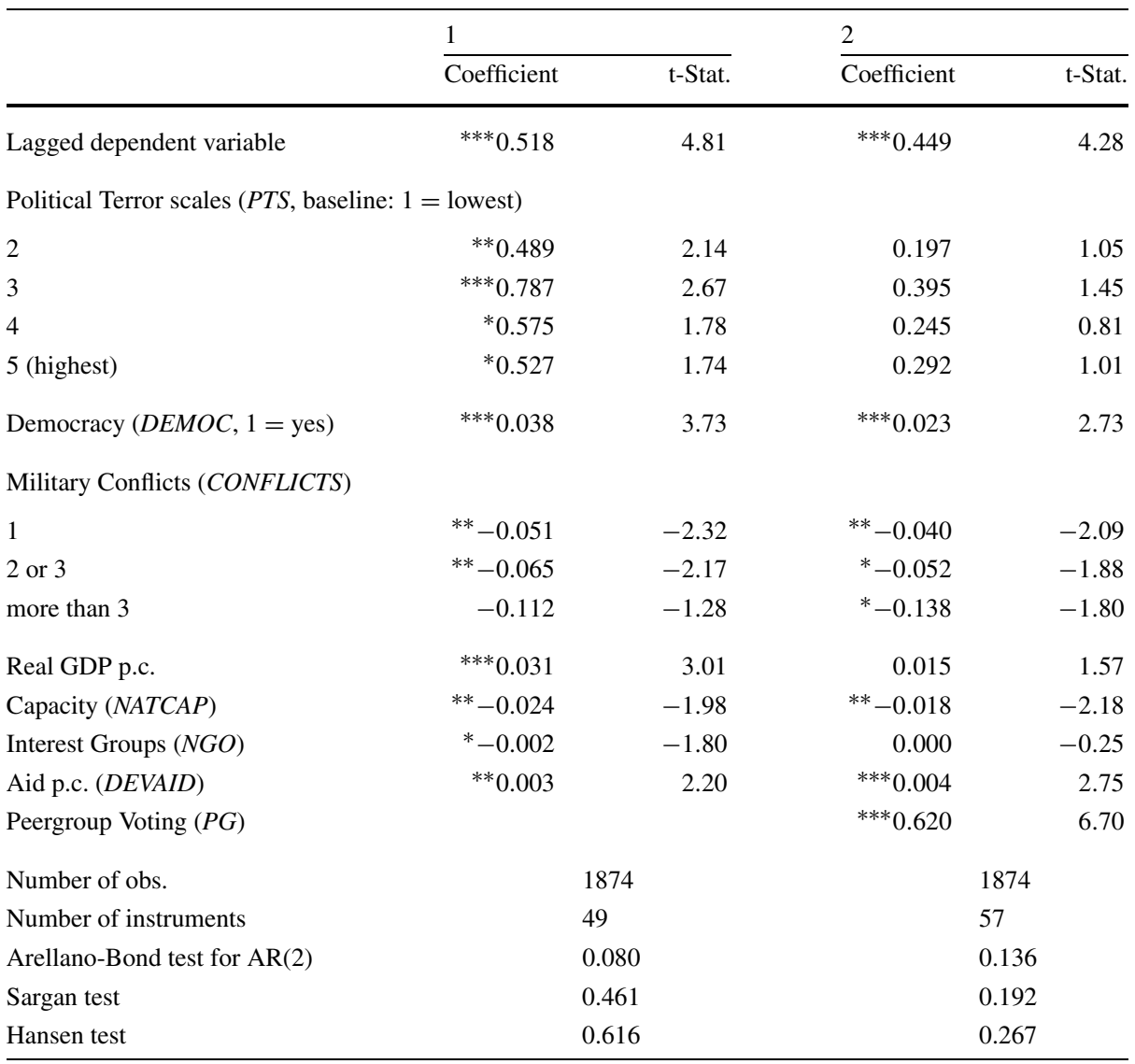

Note: OECD, Warsaw Pact membership, and year dummies included. Estimation based on annual data. $* * *, * *$ and ${ }^{*}$ symbolize significance at the 1,5 and $10 \%$ levels

main finding is that individual countries' human rights records are not influential for voting. If voting behavior inside a regional peer group of countries is controlled for, human rights variables become insignificant, unlike any other of our control variables. While it first appears that there is a relation between human rights and voting, this is not confirmed by estimations which take the dependence of voting across regions into account. This suggests that countries do not vote against human rights because their own human rights practices may be criticized. Rather, they vote against them because they belong to a particular group of countries with a particular average level of human rights. A human rights offender in a region in which human rights are respected tends to vote in favor of UN human rights resolutions, while a country respecting human rights in a region in which they are violated tends to vote against them.

Substantially, this finding implies that there is limited evidence for instrumental voting at the UNGA. Voting appears to be expressive rather than instrumental. Cohesion within regional groups is clearly important. Nevertheless, there are a number of country-specific determinants of voting. In particular, democratic participation rights matter. Furthermore, wealth, the capacity for conducting an independent foreign policy and (with less robustness) 
the amount of military conflict and the presence of human rights NGOs all significantly affect voting behavior.

A third conclusion from the paper concerns the nature of the different voting alternatives. There is much disagreement in the literature whether and how choices such as abstention and votes against may be aggregated. Our results show that these alternatives are regarded as different by UNGA members. It clearly emerges that voting against is a stronger form of opposition than abstention, rendering abstention due to indifference a reasonable hypothesis for many of the countries participating in the vote.

Acknowledgements We thank participants of the First World Meeting of the Public Choice Society (Amsterdam 2007) and Peter Calcagno for helpful comments. The first author thanks the KOF at ETH Zurich for its hospitality while this paper was written.

Open Access This article is distributed under the terms of the Creative Commons Attribution Noncommercial License which permits any noncommercial use, distribution, and reproduction in any medium, provided the original author(s) and source are credited.

\section{Appendix}

Table 10 Summary statistics of the independent variables (estimation sample)

\begin{tabular}{|c|c|c|c|c|}
\hline Variable & Mean & Std. Dev. & Min & Max \\
\hline \multicolumn{5}{|l|}{ Region Dummies } \\
\hline East Asia \& Pacific & 0.242 & 0.428 & 0 & 1 \\
\hline Eastern Europe \& Central Asia & 0.235 & 0.424 & 0 & 1 \\
\hline Latin America \& Caribbean & 0.084 & 0.277 & 0 & 1 \\
\hline Middle East \& North Africa & 0.054 & 0.226 & 0 & 1 \\
\hline South Asia & 0.254 & 0.435 & 0 & 1 \\
\hline Sub-Saharan Africa & 0.019 & 0.137 & 0 & 1 \\
\hline \multicolumn{5}{|l|}{ Religion Dummies } \\
\hline Christian & 0.517 & 0.500 & 0 & 1 \\
\hline Muslim & 0.209 & 0.406 & 0 & 1 \\
\hline Hindu & 0.032 & 0.177 & 0 & 1 \\
\hline Buddhist & 0.011 & 0.104 & 0 & 1 \\
\hline \multicolumn{5}{|l|}{ Legal heritage dummies } \\
\hline British & 0.327 & 0.469 & 0 & 1 \\
\hline German & 0.020 & 0.140 & 0 & 1 \\
\hline Scandinavian & 0.049 & 0.217 & 0 & 1 \\
\hline Socialist & 0.072 & 0.258 & 0 & 1 \\
\hline OECD Member & 0.228 & 0.420 & 0 & 1 \\
\hline Warsaw Pact Member & 0.019 & 0.136 & 0 & 1 \\
\hline \multicolumn{5}{|l|}{ Physical Integrity Rights } \\
\hline 2 & 0.246 & 0.430 & 0 & 1 \\
\hline 3 & 0.270 & 0.444 & 0 & 1 \\
\hline 4 & 0.287 & 0.452 & 0 & 1 \\
\hline
\end{tabular}


Table 10 (Continued)

\begin{tabular}{lcccc}
\hline Empowerment Rights & & & 0 & 1 \\
2 & 0.238 & 0.426 & 0 & 1 \\
3 & 0.249 & 0.433 & 0 & 1 \\
4 & 0.295 & 0.456 & & \\
Political Terror Scales & & & 0 & 1 \\
2 & 0.315 & 0.464 & 0 & 1 \\
3 & 0.247 & 0.431 & 0 & 1 \\
4 & 0.118 & 0.322 & 0 & 1 \\
5 & 0.037 & 0.189 & 0 & 10 \\
Democracy & 5.273 & 4.187 & & 1 \\
Military Conflicts & & & 0 & 1 \\
1 & 0.207 & 0.405 & 0 & 1 \\
2 or 3 & 0.119 & 0.324 & 0 & 41.354 \\
more than 3 & 0.037 & 0.189 & 0.424 & 15.671 \\
Real GDP p.c. & 7.232 & 6.955 & 0.001 & 148.000 \\
Capacity & 0.759 & 1.955 & 10.000 & 95.560 \\
Interest Groups & 62.396 & 26.107 & -0.570 & 1 \\
Aid p.c. & 4.832 & 8.473 & -1 & \\
Peergroup Voting & 0.166 & 0.704 & &
\end{tabular}

\section{References}

Alesina, A., \& Dollar, D. (2000). Who gives foreign aid to whom and why? Journal of Economic Growth, 5(1), 33-63.

Alesina, A., \& Weder, B. (2002). Do corrupt governments receive less foreign aid? American Economic Review, 92(4), 1126-37.

Andersen, T. B., Harr, T., \& Tarp, F. (2006). On US politics and IMF lending. European Economic Review, 50(7), 1843-1862.

Arellano, M., \& Bond, S. (1991). Some tests for specification for panel data: Monte Carlo evidence and an application to employment equations. Review of Economic Studies, 58(2), 277-297.

Arellano, M., \& Bover, O. (1995). Another look at the instrumental variable estimation of error-components models. Journal of Econometrics, 68(1), 29-51.

Barro, R. J., \& Lee, J.-W. (2005). IMF programs: Who is chosen and what are the effects? Journal of Monetary Economics, 52(7), 1245-1269.

Bennis, P. (1997). The United Nations and Palestine: partition and its aftermath-UN stance on Palestine's displacement by creation of Israel. Arab Studies Quarterly, 19(3), 47-77.

Bernstein, S. J., \& Alpert, E. J. (1971). Foreign aid and voting behavior in the United Nations: The admission of communist China. Orbis, 15(3), 963-977.

Bjørnskov, C. (2008). On globalization and human rights: The importance of types of globalization. Presented at the conference Beyond Basic Questions, Göttingen, October 10-11, 2008.

Black, L. D. (1968). The Strategy of foreign aid. Princeton: Van Nostrand.

Blundell, R., \& Bond, S. (1998). Initial conditions and moment restrictions in dynamic panel data models. Journal of Econometrics, 87(1), 115-143.

Boockmann, B. (2003). Mixed motives: An empirical analysis of ILO roll-call voting. Constitutional Political Economy, 14, 263-285.

Boockmann, B. (2006). Participation and voting in committees: Evidence from the ILO. Public Choice, 126, $405-427$.

Brennan, G., \& Hamlin, A. (1998). Expressive voting and electoral equilibrium. Public Choice, 95, 149-175.

Broz, J. L. (2008). Congressional voting on funding in the international financial institutions. Review of International Organizations, 3, 351-374. 
Broz, L., \& Hawes, M. B. (2006). Congressional politics of financing the International Monetary Fund. International Organization, 60(2), 367-399.

Chau, N. H., \& Kanbur, R. (2002). The adoption of international labour standards conventions: Who, when and why. In Collins, S.M., Rodrik, D. (Eds.), Brookings Trade Forum 2001.

Cingranelli, D. L., \& Richards, D. L. (1999). Measuring the level, pattern, and sequence of government respect for physical integrity rights. International Studies Quarterly, 43(2), 407-418.

Cingranelli, D. L., \& Richards, D. L. (2006). The Cingranelli-Richards (CIRI) Human Rights Dataset 2006, 9/27/2006, http://www.humanrightsdata.org/.

Cornett, L., \& Gibney, M. (2003). Tracking terror: The Political Terror Scale 1980-2001. Commissioned by the Human Security Centre.

Dahlberg, M., \& Johansson, E. (2002). On the vote purchasing behavior of incumbent governments. American Political Science Review, 96, 27-40.

Dreher, A., \& Jensen, N. M. (2007). Independent actor or agent? An empirical analysis of the impact of US interests on IMF conditions. Journal of Law \& Economics, 50(1), 105-124.

Dreher, A., \& Sturm, J.-E. (2006). Do IMF and World Bank influence voting in the UN General Assembly? (KOF Working Paper 137). ETH Zurich.

Dreher, A., Gassebner, M., \& Siemers, L. H.-R. (2006). Do globalization and economic freedom affect human rights? An empirical analysis. KOF, ETH Zurich.

Dreher, A., Thiele, R., \& Nunnenkamp, P. (2008). Does US aid buy UN General Assembly votes? A disaggregated analysis. Public Choice, 136(1), 139-164.

Dreher, A., Gassebner, M., \& Siemers, L. H.-R. (2007, forthcoming). Does terror threaten human rights? Evidence from panel data. Journal of Law \& Economics.

Fleck, R., \& Kilby, C. (2001). Foreign aid and domestic politics: Voting in congress and the allocation of USAID contracts across congressional districts. Southern Economic Journal, 67(3), 598-617.

Fleck, R., \& Kilby, C. (2002). Reassessing the role of constituency in congressional voting. Public Choice, 112, 31-53.

Gates, S., \& Höffler, A. (2004). Global aid allocation: Are nordic donors different? Centre for the Study of African Economies, WPS/2004-34.

Gstöhl, S. (2006). Governance through government networks: The G8 and international organizations. Review of International Organizations, 2(1), 1-38.

Hathaway, O. A. (2002). Do human rights treaties make a difference? The Yale Law Journal, 111(8), 19352042.

Hix, S., Noury, A. G., \& Roland, G. 2006. Democratic politics in the European Union (Mimeo).

Holcombe, R. G., \& Sobel, R. S. (1996). The stability of international coalitions in United Nations voting from 1946 to 1973. Public Choice, 86, 17-34.

Hosli, M. (2007). Explaining voting behavior in the Council of the European Union (Mimeo). Leiden University.

Hurwitz, L. (1975). The EEC in the United Nations: The voting behavior of eight countries, 1948-1973. Journal of Common Market Studies, 13(3), 224-243.

Kato, M. (1969). A model of US foreign aid allocation: An application of a rational decision-making scheme. In Mueller, J. E. (Ed.), Approaches to measurement in international relations. New York: AppletonCentury-Crofts.

Kegley, C. W. Jr., \& Hook, S. W. (1991). U.S. foreign aid and U.N. voting: Did Reagan's linkage strategy buy defence or defiance? International Studies Quarterly, 35(3), 295-312.

Kilby, C. (2006). Donor influence in multilateral development banks: The case of the Asian Development Bank. Review of International Organizations, 1(2), 173-195.

Kilby, C. (2009a). The political economy of conditionality: An empirical analysis of World Bank Loan disbursements. Journal of Development Economics, 89(1), 51-61.

Kilby, C. (2009b). Donor influence in international financial institutions: Deciphering what alignment measures measure. Paper presented at the Political Economy of International Organizations Meeting, Geneva, 2009.

Kim, S. Y., \& Russett, B. (1996). The new politics of voting alignments in the United Nations General Assembly. International Organization, 50, 629-652.

Landmann, T. (2005). Review Article: The political science of human rights. British Journal of Political Science, 35(3), 549-572.

Lebovic, J. H., \& Voeten, E. (2006). The cost of shame: International organizations, foreign aid, and human rights norms enforcement. Paper presented at the annual meeting of the International Studies Association, Town \& Country Resort and Convention Center, San Diego, California.

Ledyard, J. O. (1984). The pure theory of large two-candidate elections. Public Choice, 44, 7-41.

Levitt, S. D. (1996). How do Senators vote? Disentangling the role of voter preferences, party affiliation, and Senator ideology. American Economic Review, 86, 425-441. 
Levitt, S. D., \& Snyder, J. M. (1997). The impact of federal spending on house election outcomes. Journal of Political Economy, 105, 30-53.

Luif, P. (2003). EU cohesion in the UN General Assembly. European Union Institute for Security Studies Occasional Papers No. 49.

Lundborg, P. (1998). Foreign aid and international support as a gift exchange. Economics \& Politics, 10(2), 127-142.

Marín-Bosch, M. (1998). Votes in the UN General Assembly. The Hague: Kluwer Law International.

McKeown, T. (2009). How U.S. decision-makers assessed their control of multilateral organizations, 19571982. Review of International Organizations, 4(3), 269-291.

Morey, D., \& Lai, B. (2003). Liberalism, realism, and United Nations Voting: An empirical test of contending theories (Mimeo). Department of Political Science, University of Iowa.

Neumayer, E. (2005). Do international human rights treaties improve respect for human rights? Journal of Conflict Resolution, 49(6), 925-953.

Newcombe, H., \& Allett, J. (1981). Nations in groups (2): typical analysis of roll-call votes in the UN General Assembly (1946-1973), Dundas, Ontario, Canada. The Peace Research Institute.

Poole, K. T., \& Rosenthal, H. (1991). Patterns of congressional voting. American Journal of Political Science, $35,228-278$.

Poole, K. T., \& Rosenthal, H. (1997). Congress. A political-economic history of roll call voting. New York: Oxford.

Potrafke, N. (2009). Does government ideology influence political proximity with the US? An empirical analysis of UN General Assembly voting. Review of International Organizations, 4(3), 245-268.

Rai, K. B. (1972). Foreign policy and voting in the UN General Assembly. International Organizations, 26(3), 589-594.

Rai, K. B. (1980). Foreign aid and voting in the UN General Assembly, 1967-1976. Journal of Peace Research, 17(3), 269-277.

Richards, D. L., Gelleny, R., \& Sacko, D. (2001). Money with a mean streak? Foreign economic penetration and government respect for human rights in developing countries. International Studies Quarterly, 45(2), 219-239.

Riker, W. H., \& Ordeshook, P. C. (1968). A theory of the calculus of voting. American Political Science Review, 62, 25-42.

Roodman, D. (2005). xtabond2: Stata module to extend xtabond dynamic panel data estimator. Center for Global Development, Washington, D.C. http://econpapers.repec.org/software/bocbocode/s435901.htm.

Roodman, D. (2006). How to do xtabond2: An introduction to "Difference" and "System" GMM in Stata, Center for Global Development (Working Paper 103).

Rothenberg, L. S., \& Sanders, M. S. (2000). Legislator turnout and the calculus of voting: The determinants of abstention in the U.S. Congress. Public Choice, 103, 259-270.

Russett, B. M. (1967). International regions and the international system. Chicago: Rand McNally.

Sexton, E. A., \& Decker, T. N. (1992). U.S. foreign aid: Is it for friends, development or politics? The Journal of Social, Political and Economic Studies, 17(3 \& 4), 303-315.

Simmons, B. (2000). International law and state behavior: commitment and compliance in international monetary affairs. American Political Science Review, 94, 819-835.

Singer, J. D., Bremer, S., \& Stuckey, J. (1972). Capability distribution, uncertainty, and major power war, 1820-1965. In Russett, B. (Ed.), Peace, war, and numbers (pp. 19-48). Beverly Hills: Sage.

Snyder, J. M. Jr., \& Groseclose, T. (2000). Estimating party influence in congressional roll-call voting. American Journal of Political Science, 44, 187-205.

Stigler, G. J. (1972). Economic Competition and Political Competition. Public Choice, 13, 91-106.

Stone, R. W. (2002). Lending credibility: the International Monetary Fund and the post-communist transition. Princeton: Princeton University Press.

Stone, R. W. (2004). The political economy of IMF lending in Africa. American Political Science Review, 98(4), 577-592.

Stratmann, T. (1991). What do campaign contributions buy? Deciphering causal effects of money and votes. Southern Economic Journal, 57, 606-664.

Stratmann, T. (1998). The market for congressional votes: Is the timing of contributions everything? Journal of Law \& Economics, 41, 85-114.

Summers, R., \& Heston, A. (1991). The Penn World Table (Mark 5): An expanded set of international comparisons, 1950-1988. Quarterly Journal of Economics, 106, 327-369.

Thacker, S. C. (1999). The high politics of IMF Lending. World Politics, 52, 38-75.

Thiem, J. (2006). Explaining roll call vote request in the European Parliament (MZES Working Paper 90).

Tullock, G. (2006). The vote motive (2nd ed.) London: Institute of Economic Affairs.

Union of International Associations (2000). Yearbook of international organizations. CD-Rom. 
US Department of State (1985). Report to congress on voting practices in the United Nations. Washington, D.C.

Voeten, E. (2000). Clashes in the Assembly. International Organization, 54, 185-215.

Voeten, E. (2004). Documenting votes in the UN General Assembly. The George Washington University (http://home.gwu.edu/ voeten/UNVoting.htm).

Volgy, T. J., Frazier, D. V., \& Ingersoll, R. S. (2003). Preference similarities and group hegemony: G-7 voting cohesion in the UN General Assembly. Journal of International Relations and. Development, 6(1), 5170.

Vreeland, J. (2008). Political institutions and human rights: Why dictatorships enter into the United Nations Convention Against Torture. International Organization, 62(1), 65-101.

Wang, T.-Y. (1999). US foreign aid and UN voting: An analysis of important issues. International Studies Quarterly, 43(1), 199-210.

Windmeijer, F. (2005). A finite sample correction for the variance of linear efficient two-step GMM estimators. Journal of Econometrics, 126(1), 25-51.

Wittkopf, E. (1973). Foreign aid and United Nations votes: A comparative study. The American Political Science Review, 67(3), 868-888.

World Bank (2006). World development indicators. CD-Rom, Washington, D.C. 